\title{
Host suitability of grain sorghum and sudangrass for Pratylenchus brachyurus
}

\section{Suscetibilidade do sorgo granífero e capim-sudão a Pratylenchus brachyurus}

\author{
Victor Hugo Moura de Souza1* (D, Mário Massayuki Inomoto \\ | | | | | | | | | | | | | | | | | | | | | | | | | | | | | | | | | | | | | | | | | | | | | | | | | | | | | | | | | | | | | | | | | | | | | | | | | | | | | | | | | | | | | | | | | | | | | | | | | | | | | | | | | | | | | | | | | | | | | | | | | | | | | | | | | | | | | | | | | | | | | | | | | | | | | | | | | | | | | | | | | | | | | | | | | | | | | | | | | | | | | | | | | | | | | | | | | | | | | | | |
}

\begin{abstract}
Nowadays, the root-lesion nematode Pratylenchus brachyurus (Godfrey) is a major pest of soybean in Brazil, mainly in areas using double cropping with maize or cotton, which are suitable hosts for $P$. brachyurus. A great effort has been made to find cash crops for $P$. brachyurus management. Grain sorghum [Sorghum bicolor (L.)] was classified as a non-host for P. brachyurus but based on a single trial. It would be a valuable option as a culture for double cropping with soybean, as it is profitable and can be used in root-lesion nematode management. Sudangrass (S. bicolor var. sudanense) is not directly profitable, but Brazilian farmers favor it because it can produce pasture, green chop, silage, or hay under unfavorable hydric conditions. However, no information is available regarding the suitability of sudangrass for $P$. brachyurus. Thus, the current study aimed to assess the suitability of grain sorghum and sudangrass for $P$. brachyurus in two glasshouse trials. The first trial tested sudangrass and grain sorghum 'DKB 510', 'Dow 740', 'Dow 822', 'DKB 599', and 'AG 1040'. The second trial retested sudangrass and grain sorghum 'Dow 740' and 'DKB 599'. The results demonstrated that sudangrass and grain sorghum were suitable hosts for $P$. brachyurus. These results, in addition to those obtained for other types of sorghum, emphasize that $S$. bicolor and sudangrass should be avoided in fields infested with $P$. brachyurus, as they increase the nematode population.
\end{abstract}

KEYWORDS: root-lesion nematode; double cropping; cover crop; management of phytonematodes.
RESUMO: Atualmente, o nematoide das lesôes radiculares Pratylenchus brachyurus Godfrey é um dos principais patógenos para a soja no Brasil, principalmente em áreas com sucessão de milho ou algodão, que também são suscetíveis a P. brachyurus. Grandes esforços têm sido feitos a fim de encontrar uma cultura rentável que possa ser utilizada no manejo de $P$. brachyurus. O sorgo granífero (Sorghum bicolor L.) é relatado como resistente a $P$. brachyurus, porém com base em apenas um ensaio. Adicionalmente, o capim-sudão ( $S$. bicolor var. sudanense) não é diretamente rentável, mas é apreciado pelos agricultores brasileiros por produzir pasto, material verde picado, silagem ou feno, mesmo sob condições hídricas desfavoráveis. Entretanto, não há nenhuma informação sobre a suscetibilidade dessa cultura a $P$. brachyurus. Dentro desse contexto, o objetivo do presente trabalho foi avaliar a suscetibilidade de cultivares de sorgo granífero e capim-sudáo a $P$. brachyurus em dois ensaios em casa de vegetaçáo. No primeiro experimento, foram testados o capim-sudáo e os sorgos graníferos DKB 510, Dow 740, Dow 822, DKB 599 e AG 1040. No segundo experimento, capim-sudão e os cultivares de sorgo granífero Dow 740 e DKB 599 foram testados novamente. Os resultados de ambos os ensaios demonstraram que o capim-sudão e o sorgo granífero são suscetíveis a $P$. brachyurus. Esses resultados, mais os obtidos para outros tipos de sorgo, demonstram que $S$. bicolor e o capim-sudáo devem ser evitados em áreas infestadas com $P$. brachyurus, já que essas culturas aumentam dramaticamente as densidades populacionais do nematoide das lesóes no solo.

PALAVRAS-CHAVE: nematoide das lesôes radiculares; sucessão de culturas; culturas de cobertura; manejo de fitonematoides. 
Nowadays, the root-lesion nematode Pratylenchus brachyurus (Godfrey) is a major pest of soybean in Brazil, mainly in areas using double cropping system with maize and cotton, as the three crops are suitable hosts for the root-lesion nematode (DEBIASI et al., 2016). Pearl millet [Pennisetum glaucum (L.)], slender leaf rattlebox (Crotalaria ochroleuca G. Don), and showy rattlebox (C. spectabilis Roth) used to replace maize have been the main tools for $P$. brachyurus management in Brazil (ASMUS et al., 2016). More than seven million ha are annually sowed with showy rattlebox (ca. $4-5$ million ha) and slender leaf rattlebox (ca. 3-4 million ha) in February, aiming to reduce the density of $P$. brachyurus prior to soybean sowing in October-November. The area with pearl millet for $P$. brachyurus management was not properly estimated (personal communication from José Aparecido Donizeti Carlos, February 19, 2019, received by electronic correspondence).

Pearl millet and the rattlebox species could be used in a larger area; however, these crops are not profitable to farmers, and their implantation costs an additional US\$32.94-63.34 (ca. US\$32.94 - 43.07 for pearl millet, US\$35.47 - 38.01 for slender leaf rattlebox, and US $\$ 63.34$ for showy rattlebox / US\$ $1.00=\mathrm{R} \$ 3.95$ in May 9, 2019). In this regard, maize, cotton, and other cash crops are far more desirable to farmers.

Therefore, a great effort has been made in Brazil to find a cash crop that could be used for $P$. brachyurus management. Some authors reported that three types of sorghum [Sorghum bicolor (L.)] are suitable hosts for P. brachyurus: the silage, saccharine, and forage sorghum (INOMOTO; ASMUS, 2010; SHARMA; MEDEIROS, 1982), but grain sorghum (S. bicolor) was classified as a non-suitable host (MATALAOTE et al., 1987). Such incongruent responses might be due to the broad genetic diversity among sorghum cultivars and hybrids. If grain sorghum is positively not a good host for P. brachyurus, it would be a valuable option as a culture for double cropping with soybean, as it is a profitable culture, contrary to the rattlebox species.

Sudangrass (S. bicolor var. sudanense) is not directly a profitable culture, but Brazilian farmers favor it because it can produce pasture, green chop, silage, or hay under unfavorable hydric conditions (PACHECO et al., 2014). Moreover, sudangrass might be used as pasture for the integrated crop-livestock system (ICLS). However, in Brazil, Brachiaria grasses are much more appreciated than sudangrass for ICLS, even though their use in fields infested with $P$. brachyurus increases the risks for suitable crops, mainly soybean, as Brachiaria grasses are moderate hosts for the nematode (INOMOTO; ASMUS, 2010). The hybrid S. bicolor $\mathrm{x}$ S. bicolor var. sudanense 'BR-800' is a suitable host for $P$. brachyurus (INOMOTO; ASMUS, 2010), but sudangrass was not yet assessed for this nematode. Thus, the current study aimed to assess the host suitability of grain sorghum and sudangrass for $P$. brachyurus in two glasshouse trials.

Rosangela Aparecida da Silva (former professor of Univag, Várzea Grande, Mato Grosso; current researcher of Fundação MT,
Rondonópolis, Mato Grosso) originally isolated P. brachyurus populations, namely " $\mathrm{Pb} 23$ " from soil samples collected in a cotton field in Sapezal, Mato Grosso, Brazil, in 2002. This soil was potted, and maize (Zea mays $\mathrm{L}$.) was sowed and grown for two months. The nematodes were recovered from maize roots by blender and centrifugal flotation (COOLEN; D'HERDE, 1972), and females were picked up under stereomicroscope. Eight 8-L clay pots containing $6 \mathrm{~L}$ of moist-heat decontaminated soil $\left(121^{\circ} \mathrm{C} / 2\right.$ hours) and sowed with okra received an aqueous suspension containing 30 to 65 females. This population was maintained for $11-12$ years on okra, maize, and cotton roots until it was used as inocula for the trials.

For species identification, a species-specific reverse primer was used for the molecular diagnostic of Pb23 (MACHADO et al., 2007). In addition, specimens of each population were periodically extracted from okra, sorghum, and soybean roots and checked under a light microscope (1,000x magnification) to confirm the species identity based on morphological features (HANDOO; GOLDEN, 1989).

The inoculum consisted of an aqueous suspension containing 100 juveniles and females per $\mathrm{mL}$ obtained from a mixture of okra, sorghum, and soybean roots by a modified Baermann method (HOOPER, 1986).

Trial 1 compared grain sorghum hybrids with soybean, silage, and forage sorghum (suitable hosts for $P$. brachyurus); palisade grass [Brachiaria brizantha - moderate host according to INOMOTO et al., (2007)]; and pearl millet and showy rattlebox (non-suitable hosts). Seeds of five intraspecific hybrids of grain sorghum (S. bicolor 'AG 1040', 'DKB 510', 'DKB 599', 'Dow 740', and 'Dow 822'), one intraspecific hybrid of silage sorghum (S. bicolor 'Volumax'), two intraspecific hybrids of forage sorghum (S. bicolor 'AG 2501C' and 'Cober X04'), one cultivar of pearl millet ( $P$. glaucum 'ADR 300'), one cultivar of soybean (Glycine max 'Pintado'), and showy rattlebox (C. spectabilis 'Common') were acquired in commercial establishments. Farmers provided the seeds of nonspecified cultivars of sudangrass (S. sudanense) and palisade grass. Sixty seeds of each crop were sown in a $779-\mathrm{cm}^{3}$ plastic cup $($ diam $=11.5 \mathrm{~cm}, \mathrm{~h}=7.5 \mathrm{~cm})$ containing ca. $700 \mathrm{~cm}^{3}$ of sandy loam soil decontaminated with a $121^{\circ} \mathrm{C} / 2 \mathrm{~h}$ moist-heat cycle. Ten days after sowing, three seedlings were transplanted to $500-\mathrm{cm}^{3}$ plastic cups $($ diam $=7 \mathrm{~cm}, \mathrm{~h}=13 \mathrm{~cm}$ ) containing ca. $400 \mathrm{~cm}^{3}$ of autoclaved sandy loam soil. Twenty days after transplanting, $2 \mathrm{~mL}$ of the inoculum were poured into two holes, at 2 and $4 \mathrm{~cm}$ depth, made in the soil close to the seedlings. Therefore, the initial population density ( $\mathrm{Pi}$ ) in each pot was 200 specimens of P. brachyurus. At first, the plants were kept in a shaded room for two days to avoid heat stress in the nematode and then transferred to the glasshouse. The final population density (Pf roots) of $P$. brachyurus was assessed 87 days after inoculation (DAI), a period considered sufficient to allow a good reproduction of the nematode on soybean (SANTOS et al., 2015). 
At the time of evaluation, the pots were individually immersed in an $8,000-\mathrm{cm}^{3}$ bucket filled with $4,000 \mathrm{~cm}^{3}$ of tap water to separate roots from soil. Based on the authors' experience, the soil was not processed, as they expected to recover few nematodes from soil. Roots were washed with tap water, dried with absorbent paper, cut in $1-\mathrm{cm}$ pieces, and weighed. A subsample of $10 \mathrm{~g}$ of each pot-replicate was processed by blender and centrifugal flotation technique (COOLEN; D'HERDE, 1972). Eggs, juveniles, and females recovered from 10-g subsample roots were counted; thereafter, the number of nematodes in the total root weight was calculated. Two nematode reproduction data were determined for each replicate: nematode number per gram of fresh root $(\mathrm{Nem} / \mathrm{g}=\mathrm{Pf}$ roots $/$ root weight $)$ and reproductive factor $(\mathrm{R}=\mathrm{Pf}$ roots $/ \mathrm{Pi})$.

Trial 2 retested grain sorghum 'DKB 599' and 'Dow 740', forage sorghum 'AG 2501 c', sudangrass, pearl millet 'ADR 300 ', and showy rattlebox 'Common'. The general procedures of trial 2 were the same as trial 1 , except for a longer experimental period (92 DAI).

Sudangrass and all grain sorghum hybrids (S. bicolor 'AG 1040', 'DKB 510', 'DKB 599', 'Dow 740', and 'Dow 822') proved to be suitable for $P$. brachyurus, as they led to a pronounced increase of nematode densities in trial 1 (Table 1). The $\mathrm{R}$ values of $P$. brachyurus on sudangrass and grain sorghum, ranging from 18.0 to 52.1 , were alike or higher than those on standard suitable hosts (soybean, forage, and silage sorghum). The values of Nem/g, another variable for host suitability that indicates the capacity of each gram of root to nourish or sustain the nematode, were equally high on grain sorghum, ranging from 249 to 1,071 .
The results of trial 2 confirmed those of trial 1 . The $\mathrm{R}$ values of $P$. brachyurus on sudangrass and grain sorghum hybrids assessed in this trial (S. bicolor 'DKB 599' and 'Dow 740 ') were equivalent to the $R$ on the suitable host (forage sorghum 'AG 2501 c'). However, the $\mathrm{R}$ values in sorghum were quite lower in trial 2 , when compared to trial 1 . This could be attributed to a low infectiveness of the inoculum used in trial 2. Additionally, lower values could result from the lower temperatures in trial 2 (average substrate temperature of $25.3^{\circ} \mathrm{C}$ ) than in trial $1\left(27.7^{\circ} \mathrm{C}\right)$. The temperature has a strong influence in the life cycle of $P$. brachyurus, as in all other nematode species or ectothermic animals. The effect of temperature on $P$. brachyurus was evaluated in laboratory, using excised maize roots. Maximum reproduction was reached at 25 and $30^{\circ} \mathrm{C}(\mathrm{R}=$ 10.9 and 18.2); in contrast, $P$. brachyurus population increased slowly at 15 and $20^{\circ} \mathrm{C}(\mathrm{R}=1.2$ and 3.3) and decreased at 10 and $35^{\circ} \mathrm{C}(\mathrm{R}=0.8$ and 0.2$)$ (OLOWE; CORBETT, 1976). These are reasons to include standard suitable and non-suitable hosts for proper comparison.

Therefore, the current results were strongly divergent from those by MATALAOTE et al. (1987), who tested 10 grains of sorghum for $P$. brachyurus reproduction and reported a decrease in five cultivars $(\mathrm{R}=0.3-0.8)$, maintenance in one $(\mathrm{R}=1.0)$, and a low increase in four $(\mathrm{R}=1.2-2.1)$. The differences between MATALAOTE et al. (1987) and the current study might be due to the genetic diversity of sorghum; however, the most feasible reason is the distinct experimental conditions, mainly temperature. Perhaps, the temperature or another environmental factor in the trial by MATALAOTE et al. (1987) was not favorable for $P$. brachyurus movement in

Table 1. Reproductive factor (R) and nematodes per gram of fresh root (Nem/g) of Pratylenchus brachyurus on sudangrass and grain sorghum in comparison with soybean, showy rattlebox, forage, and silage sorghum ${ }^{2}$.

\begin{tabular}{|c|c|c|c|c|}
\hline \multirow{2}{*}{ Treatments } & \multicolumn{2}{|c|}{ Trial 1} & \multicolumn{2}{|c|}{ Trial 2} \\
\hline & $\mathbf{R}$ & Nem/g & $\mathbf{R}$ & $\mathrm{Nem} / \mathrm{g}$ \\
\hline Grain sorghum ‘DKB 510’ & $52.1 \mathrm{a}$ & $841 a b$ & - & - \\
\hline Grain sorghum ‘Dow 740’ & 49.9 a & $1,071 \mathrm{a}$ & $11.8 \mathrm{a}$ & $292 a b$ \\
\hline Sudangrass ‘Common' & 39.7 a & $843 a b$ & $16.5 \mathrm{a}$ & 428 a \\
\hline Grain sorghum 'Dow 822' & $36.1 \mathrm{a}$ & $763 a b$ & - & - \\
\hline Forage sorghum 'AG 2501 c' & $35.3 \mathrm{a}$ & $502 a b c$ & $10.4 \mathrm{a}$ & $156 a b$ \\
\hline Grain sorghum ‘DKB 599’ & $26.3 a$ & $537 a b c$ & $10.6 \mathrm{a}$ & $248 a b$ \\
\hline Forage sorghum 'Cober X04' & $23.7 \mathrm{a}$ & $429 a b c$ & - & - \\
\hline Grain sorghum 'AG 1040' & $18.0 \mathrm{ab}$ & 249 bc & - & - \\
\hline Silage sorghum 'Volumax' & $17.8 \mathrm{ab}$ & $239 \mathrm{bc}$ & - & - \\
\hline Soybean 'Pintado' & $6.5 \mathrm{bc}$ & $291 \mathrm{abc}$ & - & - \\
\hline Palisade grass & $3.3 \mathrm{~cd}$ & $83 \mathrm{c}$ & - & - \\
\hline Pearl millet 'ADR 300' & $0.9 \mathrm{de}$ & $27 \mathrm{c}$ & $0.7 \mathrm{~b}$ & $46 c$ \\
\hline Showy rattlebox 'Common' & $0.1 \mathrm{e}$ & $1 \mathrm{c}$ & $0.2 \mathrm{~b}$ & $6 c$ \\
\hline
\end{tabular}

${ }^{2}$ Experiments 1 and 2 (values represent means of six pot-replicates). Means followed by the same letter in a column did not differ according to Tukey's test $(p=0.05)$. 
soil, and/or infection/colonization/reproduction in roots. In addition, other types of sorghum (saccharine, forage, silage), including sudangrass, have proved to be suitable for P. brachyurus in current and previous trials (INOMOTO; ASMUS, 2010; SHARMA; MEDEIROS, 1982).

The suitability of sudangrass ( . bicolor var. sudanense) for $P$. brachyurus is congruent with the general response of various types of sorghum (S. bicolor), including the forage sorghumsudangrass hybrid (S. bicolor $\mathrm{x}$ S. bicolor var. sudanense 'BR 800') (INOMOTO; ASMUS, 2010). As sudangrass is a more suitable host for $P$. brachyurus than palisade grass (B. brizantha) (Table 1 ), replacing Brachiaria grasses in ICLS is not a good option.

In conclusion, grain sorghum and sudangrass plants are suitable hosts for $P$. brachyurus. These results, in addition to previous data on other types of sorghum (S. bicolor), emphasize that sorghum and sudangrass must be avoided in fields infested with $P$. brachyurus, as they strongly increase the nematode population in soil.

\section{ACKNOWLEDGEMENTS}

This study was financed in part by the Coordenação de Aperfeiçoamento de Pessoal de Nível Superior - Brasil (CAPES) - Finance Code 001. We also thank the Conselho Nacional de Desenvolvimento Científico e Tecnológico (CNPq) for the financial support.

| || | | | | | | | | | | | | | | | | | | | | | | | | | | | | | | | | | | | | | | | | | | | | | | | | | | | | | | | | | | | | | | | | | | | | | | | | | | | | | | | | | | | | | | | | | | | | | | | | | | | | | | | | | | | | | | | | | | | | | | | | | | | | | | | | | | | | | | | | | | | | | | | | | | | | | | | | | | | | | | | | | | | | | | | | | | | | | | | | | | | | | | | | | | | | | | | | | | | | | | | | | REFERENCES

ASMUS, G.L.; INOMOTO, M.M.; BORGES, E.P. Manejo de Pratylenchus brachyurus com crotalária ou milheto em área de produção de soja. Dourados: Embrapa Agropecuária Oeste, 2016. 19p. Available from: <https://ainfo.cnptia.embrapa.br/digital/bitstream/ item/148831/1/BP732016.pdf>. Accessed on: Feb. 202019.

COOLEN, W.A.; D'HERDE, C. J. A Method for the Quantitative Extraction of Nematodes from Plant Tissue. Ghent: State Nematology and Entomology Research Station, 1972.

DEBIASI, H.; FRANCHINI, J.C.; DIAS, W.P.; RAMOS JUNIOR., E.U. BALBINOT JR., A.A. Práticas culturais na entressafra da soja para o controle de Pratylenchus brachyurus. Pesquisa Agropecuária Brasileira, Brasília, v.51, n.10, p.1720-1728, 2016. http:// dx.doi.org/10.1590/s0100-204x2016001000003

HANDOO, Z.A.; GOLDEN, M.A. A key and diagnostic compendium to the species of the genus Pratylenchus Filipjev. Journal of Nematology, Lawrence, v.21, n.2, p.202-218, 1989.

HOOPER, D.J. Extraction of free-living stages from soil. In: SOUTHEY, J.F. (Ed.). Laboratory Methods for Work with Plant and Soil Nematodes. Her Majesty's Stationery Office, London, 1986. p.5-30.

INOMOTO, M.M.; ASMUS, G.L. Host status of graminaceous cover crops for Pratylenchus brachyurus. Plant Disease, St. Paul, v.94, n.8, p.1022-1025, 2010. https://doi.org/10.1094/PDIS-94-8-1022

INOMOTO, M. M. .; MACHADO, A. C. Z. .; ANTEDOMENICO, S. R. Reação de Brachiaria spp. e Panicum maximum a Pratylenchus brachyurus. Fitopatologia Brasileira, v. 32, p. 341-344, 2007.
MACHADO, A.C.Z.; FERRAZ, L.C.C.B.; OLIVEIRA, C.M.G. Development of a species-specific reverse primer for the molecular diagnostico f Pratylenchus brachyurus. Nematropica, v.37, n.2, p.249-257, 2007.

MATALAOTE, B.; STARR, J.L.; FREDERIKSEN, R.A.; MILLER, F.R. Host status and susceptibility of sorghum to Pratylenchus species. Revue de Nématologie, Paris, v.10, n.1, p.81-86, 1987.

OLOWE, T. .; CORBETT, C. D. M. Aspects of the biology of Pratylenchus brachyurus and P. zeae. Nematologica, v. 22, p. 202-211, 1976.

PACHECO, R.F.; ALVES FILHO, D.C.; BRONDANI, I.L.; NORNBERG, J.L.; PIZZUTI, L. A.D.; CALLEGARO, A.M. Características produtivas de pastagens de milheto ou capim sudão submetidas ao pastejo contínuo de vacas para abate. Ciência Animal Brasileira, Goiânia, v.15, n.3, p.266-276, 2014. Available from: <http://www.scielo.br/pdf/cab/v15n3/ a04v15n3.pdf>. Accessed on: Feb. 28 2019. https://doi. org/1 10.1590/1809-6891v15i324387

SANTOS, T.F.S.; POLIZEL, A.C.; RIBEIRO, N.R.; SILVA, T.J.A.; GUIMARÃES, S.L. Reprodução de Pratylenchus brachyurus em diferentes níveis de inóculo e tempo de avalição em três cultivares de soja. Nematropica, DeLeon Springs, v.45, n. 1, p.43-50, 2015.

SHARMA, R.D.; MEDEIROS, A.C.S. Reações de alguns genótipos de sorgo sacarino aos nematoides Meloidogyne javanica e Pratylenchus brachyurus. Pesquisa Agropecuária Brasileira, Brasília, v.17, n.5, p.697-701, 1982. 